\title{
A importância da voz nos compêndios retóricos oitocentistas e nos manuais de fala pública da modernidade
}

Ana Paula Zanesco Salgado*

Carlos Piovezani**

\section{Resumo}

O presente trabalho busca identificar o que se diz sobre a voz humana e como são formulados os enunciados a seu respeito no campo da oratória, a partir de uma abordagem discursiva e comparativa. Fundamentado na Análise do discurso, derivada dos trabalhos de Michel Pêcheux e seu grupo, este artigo visa a descrever, interpretar e cotejar os discursos metalinguísticos sobre a voz em duas condições de produção distintas, a saber, em compêndios de retórica do século XIX e em manuais de fala pública do século XXI, publicados no Brasil. Os resultados das análises permitem constatar que, embora haja importantes diferenças no que se diz sobre voz, decorrentes das diversas condições de produção, entre o conjunto de técnicas que avaliam e prescrevem padrões para falar em público, ocorrem, não raras vezes, consideráveis identidades, especialmente naquilo que se diz sobre a importância da voz para a persuasão.

Palavras-chave: Análise do discurso. História das ideias linguísticas. Voz. Retórica. Fala pública.

\section{Introdução}

\begin{abstract}
A compreensão do funcionamento dos discursos metalinguísticos sobre os usos e efeitos da voz e dos discursos que descrevem, avaliam e prescrevem padrões de correção e eficiência para os desem-
\end{abstract}

* Mestranda em Linguística na Universidade Federal de São Carlos. Desenvolveu pesquisa na área de Retórica e Análise do Discurso (AD), e, atualmente, é pesquisadora nas áreas de AD e História das Ideias Linguísticas (HIL), nas quais analisa os discursos sobre a língua e a voz nas falas públicas e privadas da sociedade brasileira oitocentista. E-mail: ap.zanesco@yahoo.com.br

* Professor associado do Departamento de Letras e do Programa de Pós-Graduação em Linguística da Universidade Federal de São Carlos e pesquisador do CNPq. Fez graduação em Letras na Universidade Federal de Mato Grosso do Sul (UFMS/Dourados), mestrado e doutorado em Linguística e Língua Portuguesa na Universidade Estadual Paulista (UNESP/Araraquara) e estágio de doutorado na Université de Paris III / Sorbonne Nouvelle. Fez ainda pós-doutorado na École des Hautes Études en Sciences Sociales (EHESS/Paris) e na Universidade Estadual de Campinas (Unicamp). Atua na área de Teoria e análise linguística, com ênfase em Análise do discurso e História das ideias linguísticas. Pesquisador na área de produção do discurso político e de práticas e representações da fala pública. E-mail: cpiovezani@ufscar.br

Data de submissão: 03 dez. 2019 - Data de aceite: 07 jan. 2020 http://dx.doi.org/10.5335/rdes.v16i1.8927 
penhos da ação de falar em público, é condição necessária para que constatemos e divulguemos à sociedade o fato de que as práticas e as ideias linguísticas respondem ao que se diz a seu respeito e a propósito dos sujeitos e dos grupos sociais que delas se valem. Por essa razão, cremos ser fundamental demonstrar que certas características e concepções das representações da fala pública, em geral, e da voz, em seu interior, são reiteradas até os dias de hoje, ao passo que outras já foram modificadas ou substituídas. A conservação ou a modificação histórica dessas características e concepções revelam suas filiações a diversos discursos e estes, às posições ideológicas que estão em jogo no processo socio-histórico; o que corresponde, em outras palavras, à identificação dos sujeitos às distintas formações discursivas.

Pretendemos em nosso trabalho trazer à superfície os enunciados que falam sobre a voz em materiais que normatizam seu uso e discuti-los por meio de uma análise comparativa e discursiva. Os trechos analisados foram retirados de compêndios utilizados no século XIX e de manuais para falar em público do século XXI. Entre as obras oitocentistas, trazemos: Compendio Rhetorico, ou Arte completa de Rhetorica, de Bento Rodrigo Pereira de Soto-Maior e Menezes, publicada em 1794; Lições elementares de eloquência nacional, de Francisco Freire de Carvalho, publicada em 1834; e Compendio de Rhetorica e Poética, de Manoel da Costa Honorato, publicada em 1879. Já os manuais do século XXI que figuram em nossa análise são: Voz e Corpo na TV, escrito por Leny Kyrillos, Cláudia Cotes e Deborah Feijó e publicado em 2003; Como falar em público: Técnicas de comunicação para apresentações, de Izidoro Blikstein, publicado em 2006; e Como falar corretamente e sem inibições, de Reinaldo Polito, publicada em 2013 sua 111ª edição. Examinaremos como foram formulados os seus dizeres, quando foram e para quem o foram, a fim de mais bem interpretar a presença de certos discursos que se encontram na constituição destes enunciados.

Concentrar-nos-emos em enunciados que tratem da importância atribuída pelos retores e autores dos manuais de fala pública à voz no exercício da fala pública e do seu papel em relação aos demais elementos que concorrem para a produção da persuasão. Notaremos que existem diferentes percepções sobre o papel e o uso da voz e seus efeitos na oralidade, mas encontraremos também ideias que sobreviveram à passagem entre os dois períodos e entre os dois tipos de obras aqui abordados.

Percorreremos, primeiramente, algumas das obras clássicas que serviram de base para o desenvolvimento dos compêndios oitocentistas. Aristóteles e Quintiliano são recorrentemente aludidos e citados nas páginas de Francisco Freire 
de Carvalho, Bento Rodrigo Pereira de Soto-Maior e Menezes, Manoel da Costa Honorato, Miguel Sacramento Lopes Gama e outros responsáveis por elaborar estes materiais. Em seguida, passaremos para a contextualização e análise dos enunciados dos compêndios, avançando até os dias de hoje com o exame dos segmentos retirados dos manuais.

\section{A oratória clássica}

Aimportância da voz para a persuasão é um tema que vem sendo discutido há mais de dois mil anos por grandes estudiosos da retórica, muito consultados pelos escritores de compêndios brasileiros. Entre os mais citados, figuram Aristóteles e Quintiliano, cujas obras trazem concepções que, em certos aspectos, divergem entre si sobre o papel da voz na arte da persuasão, revelando as diferenças entre as tradições oratórias grega e latina.

Em Retórica, obra de Aristóteles composta por três livros e finalizada no século IV a.C., o terceiro livro é dedicado à descrição dos preceitos para o desempenho oratório propriamente dito, ao qual os latinos chamaram de actio, e nele são atribuídos os seguintes valores à voz:

A pronunciação assenta na voz, ou seja, na forma como é necessário empregá-la de acordo com cada emoção (por vezes forte, por vezes débil ou média) e como devem ser empregues os tons, ora agudos, ora graves ou médios, e também quais os ritmos de acordo com cada circunstância (ARISTÓTELES, 2005, p. 242).
Todavia, uma vez que toda a matéria concernente à retórica está relacionada com a opinião pública, devemos prestar atenção à pronunciação, não porque ela em si é justa, mas porque é necessária. Pois o que é justo é que deve ser almejado num discurso, mais do que desagradar ou agradar. Justo é competir com os fatos por si só, de forma que todos os elementos exteriores à demonstração são supérfluos. Em todo caso, ela é extremamente importante, como foi dito, por causa do baixo nível do auditório (ARISTÓTELES, 2005, p. 242-243).

Vemos aqui que Aristóteles associa o tom de voz à manifestação da emoção na fala. O tom e o ritmo da voz devem estar "de acordo" com a emoção e com a circunstância na qual se fala, indicando que a voz deve acompanhar a ideia que pretendemos transmitir. No segundo enunciado, afirma-se que o cuidado com a pronunciação, que Aristóteles considera supérfluo em comparação com a exposição dos fatos, é necessário, especialmente quando o "nível" do auditório é baixo. A pronúncia, segundo o filósofo grego, movimenta mais o gosto e a sensibilidade dos ouvintes do que a sua racionalidade. Desta forma, podemos depreender que, para Aristóteles, quanto mais baixo o "nível" do público, maior a necessidade de se utilizar de recursos dramáticos e que apelem para outros aspectos da audiência, que não a sua razão. $\mathrm{O}$ segmento a seguir, retirado de um capítulo do livro (In)subordinações contemporâneas, justifica a relação entre a utilização da voz na persuasão e a depreciação de auditórios populares manifestada em obras clássicas: 
Mas talvez aí resida uma clivagem ainda mais profunda: a que opõe no seio da democracia grega e da república romana uma aristocracia ilustrada a uma plebe analfabeta. Desse modo, a ação oratória e em seu interior os usos da voz tornam-se superiores a outros domínios e recursos retóricos, simplesmente porque o público ouvinte estaria aquém dos bons níveis de raciocínio lógico e da sofisticação erudita (PIOVEZANI, 2016, p. 85).

Cerca de 400 anos mais tarde, com a publicação de Instituição Oratória, Quintiliano concede grande relevância à voz, também no arrebatamento do auditório e traz um novo aspecto, atrela à voz a função de identificadora de certas qualidades do orador.

Quanto à pronúncia, ela possui uma eficácia e um poder surpreendentes no discurso: a qualidade do que nós compusemos em nosso espírito importa menos do que a maneira pela qual nós o exprimimos. Com efeito, a emoção do interlocutor depende do que ele ouve (QUINTILIANO, 2003, Livro XI, cap. 3,2 e 14, p. 222).

[...] Toda ação comporta dois elementos, a voz e o gesto, que agem um sobre os olhos e a outra sobre os ouvidos; ou seja, os dois sentidos pelos quais toda impressão penetra na alma (QUINTILIANO, 2003, Livro XI, cap. 3,2 e 14, p. 225).

As regras para a pronúncia são as mesmas que aquelas para o próprio estilo. Este último deve ser correto, límpido, elegante e bem adaptado; do mesmo modo, a ação oratória será correta, ou seja, sem defeitos, se a emissão da voz for fácil, nítida, agradável, bem romana, isto é, sem sotaque campesino nem estrangeiro. [...] porque os homens se reconhecem por suas diferentes maneiras de pronúncias, assim como reconhecem o bronze por seu timbre (QUINTILIANO, 2003, Livro XI, cap. 3, p. 30-31).
A vinculação da voz com a transmissão da emoção aos ouvintes é reiterada por Quintiliano no primeiro trecho. A voz é fundamental para a penetração das palavras do orador na alma do ouvinte - veja aqui que ele fala de "alma" e não "intelecto". A voz, portanto, serve para convencer o público em sua sensibilidade. Além disso, nota-se uma nova atribuição à voz no segundo enunciado: a ela cabe desempenhar a função de nos posicionar socialmente diante do público. Ou seja, é pela pronúncia, pelo modo que utilizamos nossa voz, que reconhecemos aquele que fala em suas origens e papéis sociais, qualidades determinantes para a aceitação do público. Quintiliano alia as características "fácil, nítida, agradável, bem romana" ao falante não campesino e não estrangeiro, reforçando que os dizeres fora deste padrão não seriam bem recebidos.

Assim, a voz, de acordo com Aristóteles e Quintiliano, é necessária para mover os afetos dos espectadores e dar aos ouvintes informações que identifiquem aquele que fala em sua origem e condição social. Nas obras clássicas que analisamos, tais propriedades da voz são cruciais para viabilizar, ou não, a anuência do público e a persuasão atinge êxito muito mais pelos aspectos sensíveis da comunicação do que pelos aspectos racionais e argumentativos, principalmente quando mencionam públicos de classes sociais menos privilegiadas. Esta rápida 
observação dos enunciados retirados das obras de Aristóteles e Quintiliano serve para compreendermos como vinha sendo concebido o papel da voz nos materiais que serviram de consulta para a formulação dos compêndios e manuais brasileiros. Ainda que alguns dos manuais do século XXI não citem nomes tradicionais da retórica, estes estão presentes naqueles na medida em que fazem parte da história deste saber e em que o discurso sobre a relevância da voz se conserva na longa duração histórica, funcionando como um continuum, num processo em que certos sentidos perduram e outros vão sendo transformados ou apagados.

\section{A voz nos compêndios oitocentistas}

Até a segunda metade do século XVIII, os jesuítas eram os maiores responsáveis pelo ensino e estudo da retórica no Brasil. A Companhia de Jesus ministrava a disciplina embasada principalmente nos ensinamentos de Aristóteles, de São Tomás de Aquino e da Bíblia. Contudo, em 1759 , os padres jesuítas foram expulsos da colônia e as Reformas Pombalinas, com seu despotismo esclarecido, vieram logo em seguida a fim de diminuir o atraso científico e cultural do Império, promovendo, entre outras coisas, uma reformulação no ensino.
O historiador José Murilo de Carvalho comenta que Luís Antônio Verney, responsável pela modernização da educação no período, em sua obra $O$ Verdadeiro Método de Estudar, de 1746, ao analisar os tratados jesuíticos de eloquência,

[...] ridiculariza o excesso de citações de frases e de autores, as citações fora de propósito, as repetições inúteis, a exibição fútil de erudição, os títulos estrambóticos e obscuros e até mesmo a imperícia na elocução (CARVALHO, 2000, p. 132).

Verney, assim como Quintiliano, concebia a retórica como uma arte necessária para o cotidiano dos indivíduos, útil não só nas tribunas, mas também nas situações corriqueiras da vida.

Desta forma, a retórica, ao contrário de ser substituída, foi reforçada nas escolas. A valorização da oralidade alinhava-se com as características de uma época em que a maioria das pessoas não liam e nem escreviam. Falar bem e com clareza significava pensar igualmente bem e com clareza, explicitando a influência iluminista no discurso das obras de eloquência. A citação de Lectures on Rhetoric and Belles Lettres, um manual de retórica publicado em 1787 e escrito por Hugh Blair, reitera o quão importante era considerado o estudo da eloquência para o aperfeiçoamento intelectual: 
All that regards the study of eloquence and composition merits the higher attention upon this account, that it is intimately connected with the improvement of our intellectual powers. For I must be allowed to say, that when we are employed after a proper manner in the study of composition, we are cultivating reason itself. True rhetoric and sound logic are very nearly allied. The study of arranging and expressing our thoughts with propriety, teaches to think as well as to speak, accurately (BLAIR, 1787, p. 8). ${ }^{1}$

Entre os aspectos do ensino de retórica que foram atualizados, a partir da segunda metade do século XVIII, estão a utilização das línguas vernáculas em detrimento do latim; o uso de obras estrangeiras contemporâneas para a elaboração dos materiais de ensino, como Lectures de Blair; a inserção de exemplos da prosa e da poesia do português, como Camilo Castelo Branco e Almeida Garret; e a inclusão de trechos de discursos realizados no Brasil e da mesma época da produção destes compêndios, como aqueles retirados das falas de Joaquim de Nabuco e de Rui Barbosa.

Em 1763, passa a ser obrigatória a aprovação em exames de oratória para a admissão nas universidades da Europa, o que fez com que aulas régias de retórica surgissem no Brasil, substituindo os colégios jesuítas. Tais aulas buscavam preparar jovens para o ingresso à universidade. A retórica era tão prestigiada que todos que frequentavam aulas, ainda que não planejassem obter um grau universitário, precisavam se dedicar aos seus estudos.
[As aulas régias] incluíam o ensino do vernáculo, do latim, do grego, da retórica, da poética e da filosofia racional. Apesar do pequeno número de aulas régias criadas na colônia, pode-se dizer que no início do século XIX qualquer pessoa com alguma educação acima da alfabetização elementar, em Portugal ou no Brasil, teria passado por elas e, portanto, teria alguma formação em retórica (CARVALHO, 2000, p. 133).

Os materiais didáticos publicados, voltados para a consulta de professores e alunos, traziam compilações de obras estrangeiras traduzidas para a língua portuguesa, sofrendo, muitas vezes, adaptações para que fosse possível a articulação entre autores distintos. $\mathrm{O}$ fragmento seguinte, destacado da obra A Fonte Subterrânea, indica as conjugações teóricas realizadas no compêndio de Freire de Carvalho.

Além de terem sido adotadas como livros de estudo do Colégio Pedro II em diversos anos da década de 1860, os manuais de eloquência e de poética de Francisco Freire de Carvalho serviam de base para muitos de nossos retóricos. Uma de suas contribuições foi fornecer um modelo que permitia conjugar os elementos modernos trazidos por Hugh Blair com o complexo quadro de classificação dos ornamentos que o professor de Edimburgo abandonara e que nossos retores manterão nos seus compêndios (MARTINS, 2005, p. 38).

Como se vê, algo característico dos compêndios de retórica do século XIX da língua portuguesa era a articulação de noções mais modernas que valorizavam o raciocínio lógico, advindas de obras do final do século XVIII, com a já antiga tradição latina de incluir em seu ensino 
retórico um número expressivo de tropos e figuras - Freire de Carvalho, por exemplo, menciona 64 tipos diferentes em seu compêndio.

Figurando entre os conhecimentos básicos exigidos de estudantes brasileiros que desejavam obter algum grau de instrução, a retórica contribuía com a formação humanística e esclarecida dos jovens e era responsável por propagar a cultura erudita nacional, entendida aqui por obras tanto brasileiras quanto portuguesas. A disciplina englobava, além da poética, "exercícios de composição, tanto em prosa como em verso, análise crítica dos clássicos portugueses; discursos, narrações, declamações, história da literatura portuguesa, e nacional" (MELO, 2009, p. 131). Martins (1988), em sua obra História da Língua Portuguesa, ressalta a influência que retórica exercia na formação da cultura brasileira durante o século XIX.

A retórica que atesta a importância da oralidade num país em que o hábito da leitura era muito restrito, impregnou, de forma ora mais, ora menos acentuada, não só a imprensa de caráter político, como também o teatro, a poesia e o romance de período (MARTINS, 1988, p. 12).

A obra, cujo enunciado analisaremos a seguir, é mais um indicativo da expansão do alcance da retórica nessa época. Compendio Rhetorico, ou Arte completa de Rhetorica, de Bento Rodrigo Pereira de Soto-Maior e Menezes, foi publicada em 1794 e, ao contrário da maioria dos compêndios, destinava-se ao público em geral, e não exclusivamente para os iniciantes e iniciados que possuíam maior familiaridade com a arte retórica mediante sua instrução formal. No próprio subtítulo encontra-se a seguinte recomendação que aqui colocamos com a ortografia atualizada: "com método fácil, para toda pessoa curiosa, sem frequentar as aulas, saber a Eloquência”, o que indica que o autor acreditava existir uma demanda fora do universo acadêmico para o consumo desta obra. Por essa razão, o compêndio de Menezes apresenta, aparentemente, uma semelhança didática $\mathrm{e}$ editorial com os manuais de fala pública que também serão analisados.

Vejamos a seguir dois segmentos retirados da obra de Menezes. O primeiro traz uma citação traduzida de Cícero que trata da relevância da voz para a persuasão e o segundo segmento nos informa qual a consequência de uma colocação equivocada do tom de voz.

Porém a suavidade da voz, a compostura do rosto, a demonstração do pejo, a modéstia das palavras; e o parecer que obra constrangido, e obrigada, quando toca algum ponto áspero; são as coisas, que mais ajudam no Orador (CÍCERO, 55 a.C., p. 182-184, apud MENEZES, 1794, p. 31-32, grifo nosso).

Porque não há coisa, que mais deslustre uma Oração, por boa que seja, do que expô-la com total Unissonância, sem a diversidade de vozes, e som, que pedem as diferentes matérias, de que o Orador fala; e o lugar, e auditório, diante de quem fala, e ora (MENEZES, 1794, p. 274, grifo nosso). 
O uso dos verbos "ajudar" e "deslustrar" destacados por nós nos enunciados aponta para uma visão auxiliar da voz na fala. Sua importância aparece significativamente reduzida nestes enunciados em comparação com aquilo que foi dito por Aristóteles e Quintiliano. No primeiro trecho, ela contribui para a persuasão, mas não é a grande responsável por ela, apenas auxilia o orador neste objetivo ao servir de evidência da sua despretensão e naturalidade, indicando sua boa fé e contribuindo para a formação de um ethos favorável. No segundo segmento, a voz está colocada como forma de polimento, um acabamento atraente dado à exposição do pensamento, no intuito de contribuir para a ação persuasiva, mas não realizá-la por si só. Também neste trecho, a voz aparece em segundo plano em relação às circunstâncias do discurso oratório. Há uma preferência pela prática calculada e, ao mesmo tempo, comedida da voz, visando um tom que não se contraponha e nem se sobreponha aos argumentos e que respeite às regras de conduta referentes aos diferentes ambientes e públicos.

Nota-se, portanto, que dois fatores agem sobre o discurso acerca da voz no século XIX, a influência iluminista - que provoca uma renovação no ensino e, na retórica, a valorização da razão tanto na escolha e organização dos recursos persuasivos quanto no uso de uma eloquência que, segundo os retóricos do período, potencializava as faculdades cognitivas -, e a apreciação de práticas julgadas civilizadas, advindas de uma aristocracia europeia de tradição latina, que denotavam refinamento. Vejamos um trecho, retirado do compêndio de Manoel da Costa Honorato, que compara as retóricas antiga e oitocentista e reforça nossa constatação sobre a presença destes fatores socio-históricos no posicionamento dos materiais de eloquência acerca do estilo da fala e da voz:

A veemência do gesto e da elocução seguia necessariamente a veemência dos pensamentos:

[...] supplosio pedis, percussio frontis et femoris eram, como diz Cícero, gestos muito usados no tribunais. Hoje esses excessos seriam extravagantes e condenáveis em qualquer parte e até mesmo no teatro, donde a escola antiga já é repelida. A eloquência moderna é muito mais fria, mais temperada, e limita-se quase à simples argumentação; e esta espécie de eloquência, que os antigos chamavam de tenuis ou subtilis, tem por objeto antes instruir para convencer, do que excitar paixões, sem tomar jamais um tom de voz muito mais elevado do que convém à conversação ou ao discurso. [...] A diferença, pois, entre a retórica antiga e a moderna é bem frizante: a primeira expandia-se que sempre com entusiasmo e com plena liberdade de linguagem; a tribuna oratória era a mais forte e quase a arma única para vencer a oposição, para alcançar o triunfo e para o orador tornar-se notável; a declamação era a forma quase invariável da oratória antiga. A segunda, fruto de maduro estudo no gabinete, é mais calma, mais pacata, consegue o fim almejado quase sempre sem perturbar o ânimo alheio; é mais prudente e menos entusiasta do que a primeira, porém mais sólida e de mais seguros resultados; porque 
o orador moderno, antes de apresentar-se ao auditório, estuda o caráter dos seus ouvintes, a disposição em que estão à respeito de sua pessoa, do seu assunto, da ocasião e do lugar, e mais calmo lhes dirige a palavra, que pode elevar-se à proporção que aumentar o calor da discussão ou importância do assunto, sem contudo ser a declamação o seu caráter distintivo como acontecia nos tempos antigos (HONORATO, 1879, p. 7 - 8).

Esta adequação da fala aos "bons costumes", que inclui o tom e o volume de voz produzidos, reflete uma época em que as regras de etiqueta, que ganharam força no século XVIII, estão disseminadas e consolidadas nas sociedades europeias. Estas regras foram amplamente valorizadas entre a elite brasileira que, ainda recente e em formação, buscava ser reconhecida como tal pelos demais círculos sociais e culturais com os quais possuía relações, o que explica seu forte apego a fala ornamentada.

A defesa da simplicidade e do sólido conhecimento da matéria não implica evidentemente uma condenação do estudo da retórica, que encontra uma de suas justificativas na necessidade de ensinar os alunos a distinguir as belezas verdadeiras das falsas, os discursos dignos de louvor dos produzidos com o intuito de enredar o ouvinte por meio de falsos ornamentos. Outra razão para o seu aprimoramento reside no fato de o século XVIII ser uma época de gosto cultivado e polido, que impunha aos que desejavam sobressair-se na vida pública e nos negócios a necessidade de se expressar de maneira elegante (MARTINS, 2005, p. 18).

Examinemos três enunciados, destacados de outros dois compêndios, a saber, Lições elementares de eloquência nacional, de Francisco Freire de Carvalho, publicado em 1834 e Compendio de Rhetorica e Poética, de Manoel da Costa Honorato, publicado em 1879. Ambos foram muito utilizados no Colégio Pedro II, onde a prestigiada elite brasileira do Rio de Janeiro realizava seus estudos menores. Honorato inclusive foi professor do colégio e escreveu seu compêndio a fim de que seus alunos o consultassem em suas aulas de retórica e poética.

É certo, que o Orador deve sempre falar a linguagem da Razão, dando aos seus ouvintes sobre todos os assuntos, que tratar, ideias as mais claras, e ocupando-se incessantemente do sentido e não dos sons das palavras; porém se o seu único merecimento se reduz a raciocinar exatamente, se não possui o talento de persuadir, é fora de dúvida, que só cumprirá imperfeitamente a incumbência, que lhe está confiada (CARVALHO, 1834, p. 227-228, grifo nosso).

Na boa ordem seguem ainda a memória e a ação; a primeira consiste na conservação das coisas na inteligência de tal sorte, que delas nos recordemos quando tivermos de pronunciar o discurso; a segunda consiste na boa articulação das palavras com devidos e acomodados tons da voz, e na boa gesticulação, porque a voz e os gestos, como forma externa do discurso, muito influem para que melhor se convença, persuada ou deleite 0 auditório (HONORATO, 1879, p. 7, grifo nosso).

É mais fácil torna belo um quadro verdadeiro, do que imaginá-lo quando não existe; além disso o tom de sua voz, o seu semblante, a sua circunspecção e a doçura de suas expressões dão ainda mais força e realce a todos esses meios (HONORATO, 1879, p. 24-25, grifo nosso). 
Nos três enunciados reforça-se a ideia da voz apoiando os argumentos racionais e contribuindo para a persuasão, mas não a realizando por si só. No primeiro enunciado, Freire afirma que o orador que apenas se preocupar com a clareza de suas ideias sem, entre outras coisas, se ocupar dos sons que devem revesti-las, "só cumprirá imperfeitamente a incumbência”, o que pressupõe que aquele que fala ao público poderia, ainda assim, cumprir aquilo que pretende, mas de forma mal-acabada.

Nos dois segmentos seguintes, Honorato declara que o tom de voz acomodado às palavras, ou seja, aos conceitos que elas mobilizam, "influem para que melhor se convença, persuada ou deleite” e "dão mais força e realce" ao que se diz. Nas duas frases, fica claro que, para o professor de retórica, o convencimento, a persuasão, o deleite, a força e o realce estão já veiculados na escolha das palavras e na estrutura do discurso persuasivo, ou seja, na exposição e na organização dos argumentos, contudo, são potencializados e reforçados pela voz. Caso contrário, se o tom utilizado se sobressair, contradizendo, exagerando ou diminuindo os argumentos do orador, ou ainda, apresentando aspectos estéticos da voz desviantes do padrão aceito, a sua função de apoio aos argumentos e à construção do logos se perderá. É isso o que observamos nas citações subsequentes retiradas do compêndio de 1879 .
Pode o discurso ter sido composto com todas as regras da oratória, toda beleza do estilo, toda riqueza de imaginação, finalmente, pode ser uma obra-prima do seu gênero, e contudo ser mal pronunciado, sendo as frases ouvidas pela metade e ficando a outra metade perdida na inflexão mal cabida da voz, ou ser pronunciada com uma voz estridente, que fira os ouvidos do auditório, ou acompanhada de gestos acelerados e desapropriados aos pensamentos que se pronuncia: consequentemente esse discurso produzirá efeito contrário ao que se pretende. (HONORATO, 1879, p. 176-177, grifo nosso).

Essas inflexões, que parecem tão pouco sensíveis à primeira vista, são de uma variedade extraordinária, e formam uma espécie de pronunciação musical que escapa à análise, porém que são apercebidas perfeitamente; porque uma só inflexão falsa, ou fora de propósito, basta para destruir o efeito de um trecho, fazer um contra-senso ou transformar um pensamento nobre em uma tolice (HONORATO, 1879, p. 179, grifo nosso).

A disfonia entre voz e pensamento ou a colocação fora do padrão, ainda segundo Honorato, desvia a atenção do público do conteúdo das palavras, identificado como o principal recurso do convencimento. Há aí uma contradição: ao mesmo tempo em que a voz não está estabelecida entre os principais mecanismos persuasivos, o seu mau uso, entretanto, é altamente prejudicial, revelando em seu discurso uma relativização dos efeitos da voz na oratória.

Com relação à qualidade da voz, Honorato, assim como Quintiliano o fez, deixa transparecer que existem certos 
requisitos vocais exigidos daquele que busca tornar-se um bom orador. Condena-se a pronúncia que não faz sonora toda a fala; a voz estridente que fere os ouvidos, discriminada em um ambiente tradicionalmente masculino e machista; e a gestualização que não acompanha o tom de voz. O não cumprimento destes requisitos resultaria no descompasso entre a voz e aquilo que se deseja fazer entender pela fala e geraria, segundo os compêndios, a rejeição deste dizer pelos ouvintes.

Verificamos que há uma considerável distinção entre o que dizem Quintiliano e Aristóteles e o que defende a retórica do século XIX no Brasil. A voz, que antes era tida como um necessário recurso de convencimento devido ao seu poder de movimentar e transmitir emoções, mais importante do que os argumentos em siespecialmente quando se falava às multidões menos instruídas -, é vista como um elemento secundário no bem falar dos compêndios que aqui eram utilizados durante o século XIX, servindo mais de polimento às colocações e reforçando os argumentos do orador.

Talvez não seja excessivo relacionar nossas constatações sobre a diminuição do papel da voz na persuasão com o regime político que tínhamos no decimonônico brasileiro, como um dos decisivos elementos de suas condições de produção. Se na Grécia e em Roma podíamos encontrar uma democracia, ainda que bastante limitada em razão do grande número de pessoas que eram excluídas do exercício da cidadania, aqui no Brasil vivíamos um período em que reis, regentes e imperadores davam as cartas, sem nenhuma participação popular. Enquanto em regimes democráticos é comum a prática de assembleias populares e a concorrência de vozes, no sistema absolutista isso não ocorre, o que poderia explicar a apreciação do uso de argumentos racionais e da voz servindo de acompanhamento a eles, sem ser necessário uma maior movimentação dos afetos.

O Brasil viu, antes e depois de sua Independência, as demandas do povo serem duramente reprimidas nas múltiplas e praticamente nunca bem-sucedidas revoltas que aqui ocorreram, o que nos faz acreditar que havia pouca necessidade de se considerar as massas nos discursos eloquentes. Muito pelo contrário, o estudo da retórica era um meio de ingressar nas universidades europeias, nas quais os jovens brasileiros precisariam se dirigir com elegância e de forma civilizada, para remediarem sua "inferioridade nacional", nascidos de um país recém-descolonizado dos trópicos.

Reconhecemos, entretanto, que permaneceu ligada à voz a sua importância determinante na identificação dos "bons costumes" e das virtudes do orador, que evidenciavam sua condição educacional e socioeconômica, contribuindo para uma construção positiva de seu ethos oratório. 


\section{A voz nos manuais do século XXI}

Em nossos tempos, a palavra retórica é comumente associada à manipulação e à prática de mascarar verdades pelo uso de técnicas de argumentação, de certas escolhas enunciativas, textuais e lexicais, de determinadas sintaxes, entre outros recursos linguísticos e oratórios. Essas desconfianças em relação às técnicas de persuasão, que tendem a se estender às outras práticas de falar em público, sob a forma de suas denúncias dos embustes da oralidade e da escuta emotivas, e os entusiasmos com a escrita e a leitura racionais (BAKER; CHARTIER, 1994) não implicaram a completa eliminação de obras que se propõem a ensinar essas técnicas a serem utilizadas nas ocasiões de fala pública.

A retórica, que era antes ensinada nas escolas aos poucos que as frequentavam, gradualmente foi sendo substituída no currículo escolar pelos estudos de literatura nacional e pela ampliação dos estudos da gramática do português a partir do final do século XIX e durante a primeira metade do século XX. Daquilo que era ensinado na retórica do XIX, hoje resta apenas o ensino das figuras de linguagem na disciplina de Português. Este processo evidencia a proeminência da escrita como prática universal e saber necessário à formação de todo o indivíduo de nossa época.
Todavia, embora tenha havido um apagamento e um desprestígio da retórica, sentidos até hoje, não são poucos os cursos, as palestras e os manuais desenvolvidos para ensinar técnicas e padrões de comunicação, voltados para aqueles que desejam melhorar sua forma de se expressar. A diferença primordial aqui é como é distribuído este conhecimento e para quem ele é direcionado.

Em uma realidade na qual o conhecimento é cada vez mais especializado e voltado para a vida profissional, dentro de uma ideologia em que o tempo é visto como uma mercadoria, são poucos os sujeitos de nossa sociedade que dispõem de condições privilegiadas de vida que permitam despender seu tempo conhecendo a arte da persuasão; assim, esse campo do conhecimento parece interessar apenas àqueles que utilizam este saber para obter certos resultados profissionais. Veremos nos trechos a seguir - coletados das obras Voz e Corpo na TV, escrito por Leny Kyrillos, Cláudia Cotes e Deborah Feijó e publicado em 2003; e Como falar em público: Técnicas de comunicação para apresentações, de Izidoro Blikstein, publicado em 2006 - qual é a importância da voz no bem falar e para quem o seu cuidado é importante.

Da primeira à última página, o texto é repleto de revelações, que são úteis não só para quem usa a voz como ferramenta de trabalho (KYRILLOS; COTES; FEIJÓ, 2003, p. 12, grifo nosso). 
É leitura obrigatória também para os cantores, atores, advogados, padres, pastores, locutores de notícias, narradores de futebol, apresentadores de TV, artistas de rua, feirantes, vendedores ambulantes, camelôs. Indispensável para todos que querem dar à voz a força que as palavras merecem (KYRILLOS; COTES; FEIJÓ, 2003, p. 14, grifo nosso).

O bom desempenho de todo orador - seja ele apresentador, conferencista, professor, candidato, líder de um grupo ou administrador - começa pela fala. Qualquer tropeço ou ruído na expressão verbal pode prejudicar a recepção da mensagem, comprometendo, irremediavelmente, a principal meta do comunicador, que é, como o caro leitor bem sabe, persuadir o ouvinte/ cliente a aceitar e "comprar" a ideia central do discurso (produto, serviço, projeto, tese etc.) (BLIKSTEIN, 2006, p. 78, grifo nosso).

Nos enunciados anteriores, fica claro que os materiais são voltados para profissionais da comunicação ou que dependem também da boa comunicação para exercer sua atividade. Muito diferente daquilo que os compêndios visavam, uma formação humanística e civilizatória de quem frequentava a escola, os manuais de fala pública têm por finalidade o auxílio à vida profissional.

No primeiro trecho, há a indicação de que a voz é vista como sinônimo de ferramenta de trabalho. Já, no segundo, são enumeradas algumas das profissões que utilizam esta ferramenta e cujo estudo sobre o uso eficaz da voz se faz obrigatório. No terceiro enunciado destacado, são mencionadas as profissões: apresentador, conferencista, professor, candidato, líder de um grupo ou administrador como as áreas de trabalho que podem se utilizar do bem falar, e surge um novo termo para designar estes profissionais, comunicador.

A análise desses manuais contemporâneos de fala pública indica ter havido uma substituição do repelido termo "retórica" por “comunicação". O orador transformado em comunicador é alguém que convence seus espectadores, referidos algumas vezes como clientes, a comprar uma ideia. Na obra de Izidoro Blikstein, que trata de apresentações voltadas, principalmente, para o meio executivo, a persuasão do público resulta muitas vezes em ganhos financeiros para o próprio comunicador ou para quem ele representa. Trata-se de comunicações voltadas para investidores, representantes da imprensa (cujas reportagens podem contribuir muito para melhorar o desempenho e a imagem de uma empresa, por exemplo), sócios em uma reunião ou profissionais em uma palestra instrutiva. Por isso, convencer estas pessoas e ganhar sua atenção e boa vontade significa, de fato, vender uma ideia em troca de alguma compensação, seja um investimento, uma cobertura favorável da mídia ou popularidade entre os profissionais de seu campo de atuação. Enquanto nos compêndios o objetivo maior da retórica brasileira era falar com elegância para ter seu intelecto e sua condição social respeitados, na modernidade, os manuais buscam dirigir 
seus leitores a obterem melhores resultados em sua vida prática profissional por meio da persuasão. Revelando que ambos ocupam-se da normatização de falas de grupos sociais privilegiados em seu tempo e apresentam igual silenciamento acerca do convencimento entre sujeitos de classes desfavorecidas.

A voz como ferramenta de trabalho denota um uso mais técnico da fala e a formalização de regras que valorizam a voz e sua potencialidade persuasiva. Além dos diferentes tipos profissionais de orador que foram explicitados nos segmentos, uma das obras que trazemos em nossa análise, Voz e corpo na $T V$, é voltada especialmente para aqueles que trabalham na televisão, assinalando a existência de plataformas diferentes para a comunicação, viabilizadas pelo desenvolvimento de tecnologias e condicionadas pela forma como as utilizamos.

Diferentemente das antigas formas de falar em público, a televisão, que é assistida geralmente em ambientes privados, permite uma fala mais intimista, sem muitos sinais de rebuscamento, mas condizente com a norma culta urbana brasileira. Trata-se da produção de vozes cujos detalhes são melhores percebidos, especialmente diante da alta qualidade de imagem e som que um televisor pode transmitir. Assemelha-se a uma fala próxima, semelhante às nossas conversas privadas, de fácil entendimento, mas formulada para o recebimento de um público distante e disperso. Este tipo de fala é reconhecido por utilizar expressão corporal mais descontraída e um tom de voz amigável e não-autoritário, como se o orador estivesse se dirigindo diretamente a cada espectador.

As características e inflexões da voz com o auxílio do microfone e da função "volume" na televisão, que permite uma adequação do som aos ouvidos do telespectador, deixam muito mais explícitas as pequenas alterações que o som de nossa voz pode produzir. Há também um enriquecimento de certas qualidades da voz por intermédio das tecnologias envolvidas, o que exige um maior cuidado daquele que fala em não utilizar, por exemplo, tons muito agudos ou nasais. Isto talvez explique o maior destaque $\mathrm{e}$ cuidado à voz que é dado atualmente $\mathrm{e}$ a necessidade de seu controle.

Olhemos agora para três enunciados encontrados nessas mesmas duas obras do século XXI que falam sobre o papel na voz na fala pública.

A credibilidade conquistada pela expressão facial e corporal, desde o primeiro momento da transmissão, e os sinais vocais que a marcarão exercem uma influência determinante sobre a atitude mental do espectador, sua interação ou não com o emissor (KYRILLOS; COTES; FEIJÓ, 2003, p. 43, grifo nosso).

Os sinais vocais, combinados com os estímulos verbais e não verbais, constituem-se, então, na base da comunicação (KYRILLOS; COTES; FEIJÓ, 2003, p. 43-44, grifo nosso). 
Pois bem, a entoação pode exercer um papel decisivo para a criação de um clima afetivo favorável, na medida em que podemos imprimir ao discurso modulações ou tonalidades sonoras propícias para obter a adesão dos ouvintes/clientes (BLIKSTEIN, 2006, p. 60 , grifo nosso).

Como vemos, persistiu o papel da voz em "abrir caminhos" para a persuasão, principalmente no aspecto afetivo dos ouvintes. No entanto, inversamente ao que é explicitado nos compêndios, conquistar a dimensão emocional de quem nos ouve é extremamente valorizado, especialmente nas mídias produzidas para as massas, como já fora observado por Aristóteles. A existência de um público diversificado, que inclui indivíduos das mais diferentes origens e classes sociais, colocaria a voz entre os instrumentos de grande eficácia persuasiva.

Movimentar nossos afetos, para as obras contemporâneas, é um modo eficaz de conectar-se com o auditório, especialmente nas comunicações para um público disperso e que tem se tornado cada vez mais breves. Os poucos segundos de fala precisam convergir todas as intenções do orador a partir do uso simultâneo de vários recursos de convencimento ensinados por equipes especializadas no assunto. Desta forma, a voz é vista como "determinante", "decisiva" e está na "base da comunicação", diferentemente do que era dito nos compêndios. Não se trata de um ornamento para os argumentos, e sim uma forma de argu- mentação em si que deve ser colocada em prática de forma pensada e controlada.

Destoando destas duas obras há uma terceira que compõe o grupo de manuais do século XIX. Como falar corretamente e sem inibições, de Reinaldo Polito, publicada em 2013 sua $111^{\mathrm{a}}$ edição. Semelhante aos compêndios, o livro de Polito contém muitas citações de grandes nomes da eloquência e valoriza muito o aspecto musical da voz do orador, que deve falar com tons harmoniosos e deleitar o auditório. Ainda que seja uma obra recente, a sua concepção da importância e do papel da voz na oratória diverge dos outros manuais e apresenta ideias que se assemelham às concepções encontradas nos compêndios, exemplificadas nos enunciados seguintes:

Deixar a mente fabricar instantaneamente um pensamento, envolvê-lo com as ricas roupagens das palavras articuladas ao som da musicalidade da voz e adornadas por elegante gesticulação - eis aqui o sonho do orador no seu mais elevado desejo (POLITO, 2013, p. 191).

Ingredientes [para uma boa comunicação]:

- uma boa dose de autoconfiança

- uma colher de humildade

- uma xícara de expressão corporal, acrescida de boa voz

- riqueza de vocabulário a gosto e

- uma colher de fermento marca "entusiasmo” (POLITO, 2013, p. 228, grifo nosso).

Estes enunciados retomam a função de "acabamento" da voz em relação a outros fatores da fala. Primeiramente, afirmam que o mais elevado desejo de 
um orador é fabricar um pensamento de improviso e acrescentar a ele, entre outras coisas, a musicalidade da voz. A voz é colocada como elemento que os ouvintes desfrutam, que produz agrado, mas não concorre na persuasão nem a determina. Já no segundo trecho, na "receita" para a boa comunicação a voz não configura um ingrediente independente, mas complementa a expressão corporal, demonstrando seu caráter secundário na "mistura". Embora esta obra seja da mesma contemporaneidade dos demais manuais (sua primeira edição é do ano de 2006), ela ainda traz consigo muitos aspectos do ensino antigo de retórica, a sua descrição sobre a dimensão da voz na oratória é um deles. Contudo, há também elementos desta obra que se assemelham com as características dos manuais da modernidade, como explicações sobre o uso de microfones e sugestões de comportamento em situações modernas de fala pública. Mas a discussão destes tópicos nos desviaria do foco desta análise sobre o papel da voz e sua importância para a persuasão.

\section{Considerações finais}

A partir de nossa análise discursiva e comparativa dos materiais que prescrevem o bom uso da voz constatamos que, entre os compêndios de retórica do século XIX, o padrão do bem falar provém de manuais de eloquência europeus, espe- cialmente aqueles que tradição latina, e das normas de etiqueta advindas da aristocracia do velho continente, eventualmente acrescidos de ecos do Iluminismo. Em contrapartida, nos manuais de fala pública de nossos dias, a televisão tem exercido a maior influência sobre a construção de um padrão de fala, tendo suas características imitadas amplamente em diversos gêneros discursivos da comunicação pública.

Verificamos que, em um período cujo ensino sofria influência das ideias Iluministas e no qual uma elite brasileira em formação buscava sua afirmação, havia um privilégio da fala comedida, com a produção de uma voz que acompanhava a construção argumentativa, sem grandes arroubos, e que indicava as boas origens e a educação do orador. Mesmo porque, como dissemos, tratava-se de uma época em que havia poucas situações de fala direcionada ao povo e um maior número de ocasiões em que se dirigia a uma elite. A voz tem importância secundária nos compêndios do século XIX para a persuasão e tem como principal tarefa acompanhar o raciocínio exposto pelo orador e servir para a construção de um ethos favorável.

Já nos manuais do século XXI, a voz é mais valorizada na medida em que há um saber técnico desenvolvido sobre ela e sobre sua capacidade persuasiva, muito explorada na comunicação dirigida às massas. Seu alcance foi ampliado e inter- 
mediado pelas tecnologias de telecomunicações que hoje existem e o uso da voz tornou-se um saber especializado, cujas técnicas ensinadas por fonoaudiólogos e outros profissionais da comunicação são voltadas para um público interessado em melhorar seus resultados no trabalho. De ornamento, ou complemento do discurso oratório, a voz passa a ser considerada um importante recurso do convencimento, servindo, não só como identificador de qualidades do orador, como já ocorria, mas como ferramenta de captação do público e de manutenção de uma relação próxima entre o locutor e sua audiência, cada vez mais distantes geograficamente.

Por fim, constatamos também que nem todos os materiais publicados em uma mesma época convergem em seus discursos, já que encontramos enunciados do século XXI que se identificam mais com o que vinha sendo defendido nos compêndios oitocentistas, reproduzindo com maior afinidade os sentidos que circulavam nesta época, o que denota que ainda que pertencentes a uma mesma época os discursos não são, necessariamente, homogêneos em sua totalidade.

\section{The importance of the voice in 19 th century rhetorical compendiums and in the public speaking manuals of modernity}

\section{Abstract}

The present study aims to identify what has been said about the human voice and how has been formulated the statements about it in the field of oratory using a discursive and comparative approach. Based on the principles of Discourse Analysis, derived from the works of Michel Pêcheux and his group, the present article shows whi aims to describe, interpret and compare metalinguistic sayings regarding voice in two different historical and social contexts: nineteenth century rhetoric compendiums and 21st century public speech manuals, both published in Brazil. The results of the analyzes allow us to verify that, although there are important differences in what is said about voice in these materials, due to the different production conditions, we can still find identities between them, especially in what they say about the importance of voice to persuasion.

Keywords: Discourse analysis; History of linguistics ideas; Voice; Rhetoric; Public speech.

\section{Notas}

1 "Tudo que concerne o estudo da eloquência e composição merece a mais alta atenção por conta de, que é intimamente conectada com a melhora de nossos poderes intelectuais. Eu devo ser permitido a dizer que, quando nós somos empregados de maneira apropriada 
no estudo de composição, nós cultivamos a própria razão. A verdadeira retórica e a lógica do som são proximamente ligados. $\mathrm{O}$ estudo de arranjar e expressar nossos pensamentos com propriedade, ensina a pensar assim como a falar, acuradamente" (BLAIR, 1787, p. 8, tradução nossa).

\section{Referências}

ARISTÓTELES. Retórica. 2 $2^{\mathrm{a}}$ Ed. Lisboa: Imprensa Nacional-Casa da Moeda, 2005.

BAKER, K.; CHARTIER, R. Dialogue sur l'espace public. Revue Politix, n. 26, 1994, p. 5-22. Disponível em: <http:// www.persee.fr/doc/polix_0295-2319_1994_ num_7_26_1838>. Acesso: 11 out. 2016.

BLAIR, H. Lectures on Rhetoric and Belles Lettres. Londres: printed for A. Strahan; T. Cadell; and W. Creech in Edinburgh, 1787.

BLIKSTEIN, I. Como falar em público: Técnicas de comunicação para apresentações. São Paulo: Ática, 2006.

CARVALHO, F. F. Lições elementares de Eloquencia nacional. Rio de Janeiro: Casa d'Eduardo Laemmert, 1834.

HONORATO, M. C. Compendio de rhetorica e poetica. Rio de Janeiro: Typographia Cosmopolita, 1879.

KYRILLOS, L.; COTES, C.; FEIJÓ. D. Voz e corpo na TV: A fonoaudiologia a serviço da comunicação. São Paulo: Globo, 2003.

MARTINS, E. V. A fonte subterrânea: José de Alencar e a Retórica Oitocentista. Londrina: Editora da UEL, 2005.

MARTINS, N. S. História da língua portuguesa. v. 5 São Paulo: Ática, 1988.

MELO, C. A. O Ensino de Literatura Brasileira no Império. Travessias. Cascavel, Vol. 3, n. 3, p. 120-139, 2009. Disponível em: <http://e-revista.unioeste.br/index.php/ travessias/article/view/3448/2742>. Acesso em: 30 jan. 2016.
MENEZES, B. R. P. S. Compendio rhetorico ou arte completa de rhetorica. Lisboa: Of. de Simão Thaddeo Ferreira, 1794.

PIOVEZANI, C. Instantâneos de duradouros estigmas: consensos sobre as vozes popular e feminina (da Retórica antiga à mídia contemporânea). In: CURCINO, L.; SARGENTINI, V.; PIOVEZANI, C. (org.). (In)subordinações contemporâneas: consensos e resistências nos discursos. São Carlos: EdUFSCar, 2016 , p. 73-101.

POLITO, R. Como falar corretamente e sem inibições. 111ª ed. São Paulo: 2013.

QUINTILIANO. Institution oratoire. Paris, Les Belles Lettres, 2003. 